\title{
N.R.C. C.A.A. and the Changing Concept of Identity in Indian Perspective
}

\author{
Swarnendu Chakraborty
}

\author{
Assistant Professor in History, D.H.M. College, Bhatar, Burdwan, West Bengal, India \\ Email id-swarnenduc@aol.com
}

Received: 05 Dec 2021; Received in revised form: 25 Jan 2022; Accepted: 03 Feb 2022

(C)2022 The Author(s). Published by TheShillonga. This is an open access article under the CC BY license (https://creativecommons.org/licenses/by/4.0/)

\begin{abstract}
Migrations of tribe, people, race from one place to another for socio-economic-political reasons are as old as evolution of human race. According to archeologists, the first hominid species originated from Africa had been migrated to all over the globe. However in modern era, migrants from one country to another withoutproper documents and legal process are characterized as "Illegal immigrants." In 1947 A.D. the Indian Sub-continent had been broken in-to two separate Nation State of India and Pakistan as part of decolonization process from almost two century old British colonial regime. Very huge quantities of people had to migrate from both these two lands. The Indian Constitution had made provisions to provide Indian citizenship to the migrants through legal process. To determine who genuine Indian citizens were, the N.R.C. was first prepared in 1951. It was decided that migrants from Pakistan will be given Indian citizenship till the first January, 1966. However during the 1970s, Liberation war had been fought between Pakistan army and Bengali speaking resident of East Pakistan supported by Indian Govt. In this period, large amount of migrants from East Pakistan had been entered in different Indian provinces for economic-political stability. According to the book "Bangladesh Ke swatantra Sangram Mein Bharat Ka Yugdaan” authored by salaam Azad, the migrant no was 9899 305. After establishment of Bangladesh in 1971, Mujib Treaty was signed between India and the new Country. Indian Govt agreed to provide citizenship to all Bangladeshi migrant residing in Assam till 24.3.1971. The Assam accord signed by the Indian Govt. and Assam's ethnic associations cemented the agreement. However during the last three decades illegal migration from Bangladesh to Assam had been increased rapidly. Out of 33 districts of Assam, 9 have been over crowded with these Bangladeshi illegal immigrants. This changed demography of these districts and native ethnic -religious groups became minorities in their forefathers' land.

In 2012 a clash occurred between Bodo and Bangladeshi Muslims in the Bodoland territories in which more than 70 people had died. In this background, Assam Samhita Maha Sangh applied to Supreme Court for determining illegal migrants. In response, Indian Supreme Court ordered to update the N.R.C list in 2014.The process began in 2015. Out of 3.29 Corer applicants, 2.89 Cores have made to included themselves into the updated list. In 2016, the Indian govt. introduced Citizenship Ammendment Bill in house Of the People with the aim of providing Indian citizenship to Hindu, Sikh,Parsi, Christian, Jain and Buddhist illegal immigrants from Afganistan, Bangladesh and Pakistan. However this acts this facing criticism and protest from both opposition Indian political parties besides common masses. Several opposing party spoke person labeled this act and process as communal and anti-Muslim in nature. Besides, political parties, common people created mass protests against amendment of Indian citizenship through offline and online platform. In Sheen Bag, Delhi Muslim womenfolk actively protested. They set up community kitchen, political discourse arena, public library etc. This model was followed by other regional centers of protest through all over India.
\end{abstract}

It is my aim in this essay to analyze changing concept of Indian people's legal and political identity on the background of N.R.C, C.A.A. I will use both primary and secondary sources.

Keywords - “Migrants”, “Mujib Treaty”, “Bangladesh liberation War”, “ NR.C.”, “ C.A.A.”, “Sheen Bag”.

\section{INTRODUCTION}

The English word "citizen" is etymologically derived from Anglo-French word "Citesein" means inhabitants of a city in Fourteenth Century A.D(“Citizenship | Etymology,
Origin and Meaning of Citizenship by Etymonline," 2022). Citizenship denotes relationship between an individual and a Nation-State. It is the most privileged form of nationality which confers certain political, legal, social rights upon the 
individual both in domestic and international sectors. In return that individual is bound to provide the Nation-State allegiance, taxation and other varieties of services("Citizenship | Definition, History, \& Facts | Britannica," 2022). This concept first arose in ancient Greek City-States. A Greek Citizen was obviously a wealthy male. He was entitle to vote and liable to taxation military service. Women. Slaves and poorer section of Greek society could not become citizen("History of Citizenship," 2021). During Classical Roman and Medieval age, the concept of citizenship had evolved from time to time. In twentieth Century Indian perspective, the concept of Citizenship stresses on involvement the individual in the larger community or national imagination(Jayal, 2013). In modern concept any people/ community migrating from one country to another without legal documents/ process have been classified as "Illegal Migrant"("Definition of Illegal Alien/Immigrant," 2022).

\section{METHODOLOGY}

To conduct this study, I will use both analytical and empirical research methodology. I will use both primary and secondary sources.

\section{LITERATURE REVIEW}

I have gone through several monograph related with this topic. Important among them are "Citizenship and its discontents: an Indian history" authored by N.G.Jayal, "citizenship debate over N.R.C \& C.A.A: Assam and the politics of History" authored by N.G.Mahanta, besides different scholarly article collected from different database.

\section{BACKGROUND}

Migration of human race for better livelihood or avoid negative economic-religious-political-health related circumstances is not a new thing in world and Indian History. During pre-colonial period, there was evidence of community migration some professional social groups like artisans from one part of Indian Peninsula to another(Haynes \& Roy, 1999). Similarly, from immemorial time different foreign communities entered and settle in India as invaders/rulers, merchants, religious pilgrims/ refugees so on. They have been assimilated within Indian society with time. As poet A.Sen mentioned that diversity in religion, ethnicity, language, and customs is the driving force of India which ties different contradictory norms into a single not(Sen.A.P, 1957). Migration of Bengali speaking Muslim people towards Assam began after the battle of Plessey in 1757 in order to avoid British prosecution of Muslim elites. In 1826 British east India Company Gov. annexed native Ahom kingdom. After 1835, private English tea manufacturing companies used to bring contact labors from Bengal, Bihar, and Orissa. In 1874 Colonial administration refined Bengal's border and include some ethnic Bengali districts into newly formed Assam Province. In late Nineteenth Century, large scale industrialization process had been inaugurated by Gov. Initiatives. Western educated middle class Bengali job seekers found new opportunities in different administrative posts of this new province. Increasing Bengali socio-economic dominance in Assam made indigenous Assamese people fearful. In order to mitigate this problem British Gov. introduced "Line system" between 1916-1920 demarking migrant settlements of Barak valley. However this system increased rift between two contested communities(Sufian, 2020).

In 1947 Indian sub-continent became free from almost two hundred years colonial rule. There is a Bengali proverb "Darkness reside bellow oil lamp". It was proved true with succession events of communal conflicts, partition, and lager row of immigrants around newly fixed border line of two separate Country India and Pakistan. Indian Constitution had make provisions for nationalizing these immigrants. to determine quantity of genuine Indian citizens, N.R.C. was first prepared in 1951(Anand \& Dubey, 2018). Indian Citizenship Act (1955) provides citizenship to migrants on the basis of birth/registration/naturalization/by descent. It was declared that till First January, 1966, all the incoming migrants will be granted Indian Citizenship. In 1949, some members of Constituent assembly tried to prioritize Hindu and Sikh religious followers in granting citizenship. However their demand had not been supported by majoritarian members(Ahmed \& Khan, 2019). During the Bangladesh liberation war of 1970s, a large no of people had to migrate in different Indian Provinces for religious-political - economic push factors. Due to geographical location and common cultural sphere most of these migrants had settled in Assam. After establishment of separate Bangladesh country with political and military aids from Indian Gov., "The Mujib treaty" signed between these 2 countries had provided Indian citizenship to all incoming Bangladeshi migrants towards Assam till 24.3.1921. "The Assam Accord" signed between Indian Gov. and Assamese ethnic associations in 1985 seal the deal. However there were continuous dispute during the next 3 decades about issue of illegal Bangladeshi migration in Assam. Assamese ethnic association many times claimed that huge no of illegal Bangladeshi migration was going on in different districts due to unprotected Indo- Bangladesh border and lack of Gov. preventive initiatives. They claimed that out 
of 33 Assamese districts, 9 districts cultural and racial demography had changed(Anand \& Dubey, 2018). There were several instances of racial conflicts and violent outbreak between these two contested communities. Important among them were the massacre of Nellie (1983), Bodo- Muslim classes in Kokrajhar (1993), Barpeta (1994) etc.("A Distraught Tribal: The Genesis of Assam Ethnic Violence," 2012).

In the meantime Indian Gov. under Prime Minister A.Bazpeyi passed "The Citizenship amendment act 2003" on 7.1.2004. By this act any person born in Indian soil between 26.1.1950 -1.7.1987/ 1.7.1987-7.1.2004 from Indian citizen parents will be granted in-born Indian citizenship. This amendment first legally defined concept of illegal migrants. It also created concepts of "National Identity card" and "National Population Register"(Nirvaan.S.A. \&Goel. N, 2020). In 2012, a bitter racial clash took place between Bodo and Bengali Muslims in Bodoland territory in which more than 70 people had died. Assam samhita Mahasangh filled PIL to the Indian Supreme court. In response Indian Supreme Court asked to update the N.R.C. List in 2014. This process began in 2015. However out of 3.29 corer applicants only 2.89 cores had succeeded to include their names into the updated list(Anand \& Dubey, 2018). Indian Govt. under Prime Minister N. Modi had introduced Citizenship Amendment Bill in House of the People with aim to provide citizenship to Hindu, Sikh, Parsi, Christian, Jain and Buddhist illegal migrants from Afghanistan, Pakistan and Bangladesh. Surprisingly followers of Islam and Jewish religious faiths had been excluded from these beneficiaries. These amendments are in contrary of Article 14 of Indian Constitution which prescribed equal right to all citizens. According to global traditions, children from migrant communities can gain citizenship of birth/residing countries. So this amendment is also against India's commitment to global human rights(Ahmed \& Khan, 2019). Within a very short period, protests evolved from all over India. An important center of protest was Saheen Bag in Delhi, where Muslim women from both enlightened or not actively participated. They involved in the protest through both online and offline platform as mothers/sisters, daughters/wives. They set up community kitchen, arena for political discourse, public library and reading room etc. this model was followed by other centers all over India creating national network of solidarity and protest(Contractor, 2021). Besides common people opposition political parties criticized these amendments blaming current ruling party's anti-Muslim ideology as driving force("Mamata Banerjee on CAA, NRC: I Am Your 'Pehredar', Will Not Let Anyone Snatch Your Rights,” 2020).

\section{ANALYTICAL DISCUSSION}

The N.R.C. process in Assam has excluded 19 lakhs people from the updated list and labeled them "State-less". There are two conditions for inclusion into the updated N.R.C. list-A] Existence of a person's name into pre-1971 list. B] Family tree verifications with proper documentation. However the policy makers did not notice 2 main faults into this process. A] India is home of 223 million child brides. According to Govt. National Family Health Survey [2015-2016] out of 4 young Indian women in rural areas 1 got married before competing 18 years age(India Is Home to 224 Million Child Brides, and Counting, but That Number Can Be Reduced by OneThird, Suggests a Study, 2021). They failed to enlist their names into voter list. Any other documents relating to their natal home residency are not considered valid in the eye of concerning authorities. In case of inter-State marriages, brides are facing more difficulties to acquire residential documents from their native States due to lack of coordination between State administrative bureaucracies. So this process has turned a black eye to Indian Patriarchal social system which entwined wife's identity with husband. B] According to United Nation's Millennium Development Goals Programme, in India, out of 1.2 billion people 80 million people were below poverty level during 2018-19 financial year("Poverty in India," 2022). Naturally these people have very little education or nil education opportunities. So it's almost impossible for them to become successful in huge documentation process in front of the N.R.C. authority. Assam State Govt. had to approve this fact in judicial hearing. This updating process though began by Indian Supreme Court verdict, but no consideration alternative had not been suggested so far(Ahmed \& Khan, 2019).

Outcome of failure in N.R.C verification created masspanic especially on marginalized section of society. There are instances that daily wage earners had to waste their working days and had to travel long distance in their own expense to collect necessary documents. Many people suffered from anxiety, sleep disorder, neurological problems. There are instances that in spite of all their efforts, people could not prove their citizenship before verification authorities. In anxiety many people committed suicides(Tiwari \& Singh, 2021).

Future of these so called "stateless People" is in dilemma as they had been put in detention camps. International scholars like Haley Duschinski and organizations like Amnesty International have highlighted drawbacks of this process. In January, 2018, National Human Right Commission reported that living standard in these camps is 
not matching with national or international human right laws recommendations. Many separated children/parents/husbands/wives have not meet with each other's for years. Besides that most of the detained persons had not been able utilize right of self-defense. In result, marginalized religious/social/economic/ gendered sections of Indian society had been and will be affected most(Mander, 2018).

Meghalaya, Tripura and other North-Eastern States are connected with rest of India through Assam by "Siliguri Corridor". Assam's geographical location is very close with semi-hostile neighboring China, Nepal and Myanmar. Assam has rich natural resources like tea, petroleum, hydro-carbon etc. For these strategic-economic reasons, Assam is one of states of national importance. However, most of Assam's tea estates and other natural resources have been handled by non-Assamese ethnic people. Revenues collected from tea and energy sectors are distributed by Central Govt. Assamese people are not satisfied with this status. For regaining control over Assam's natural resources from outsiders ["Jati-Mativeti"], they lunched civil and militant movements. It is proven fact that inhabitants of North-Eastern Indian states have a sense of deprivation in comparisons with rest of India due to some cultural differences(Mukherjee.Trisha, 2022). A.Sufian has argued that to distract Assamese people's agitation against non-Assamese capitalist in Assam, B.J.P. Govt. played the "Illegal Migrant" card in Assam during General Election of 2014 and 2019 and became a dominant political force. However when updated N.R.C. list had been prepared many Hindu community members also excluded from this. "Hindutwa" is main political-religious ideology of B.J.P. For this reason, in "C.A.A." tactfully inserted Hindu nationalism targeting only Muslims as "Illegal Bangladeshi migrants" and deprived them the chance of gaining Indian citizenship(Sufian, 2020).

The concept of "National State" in Europe was build symontenously on the idea of "Social Contract". However in India this concept was created by Colonial rulers. So Indian common people generally bear more allegiance to caste, language, religion and family bond rather than Nation-State. It was only in late 19th and early 20th Century, when Indian bourgeoisie developed the concept of nationalism. M.K.Gandhi turned this nationalism into mass movement against Colonial rule. However, after independence and partition in 1947, the spirit of anticolonial nationalism faded. As evidence we can look on different national and provincial separatist movements in Maharashtra, Punjab, Assam, Gujarat, Kashmir, Nagaland, West Bengal based on caste, language and religion broke out("Separatist Movements of India," 2021). Dr.
B.R.Ambedkar realized the diverse language, religious, ethnic elements of newly formed Indian State. In order to make this newly set up Liberal Democracy successful, he gave importance to fraternity. In a political community common citizenship \{we-Ness $\}$ increase Psychological effects of shared fate and ensure ethical commitment to Nation from its members. Globalization and privatization of individuals reduced Democracy into election centered institutions all over the globe. In India, high level of economic inequality and very few attempts to provide basic facilities to poorer section will further increased divisions between different ethno-religious- cultural groups and break this Country into numerous smaller warring Successor states(Varghese et al., n.d.).

Twenty First Century is marked by remarkable improvement in Information Technology and communication. It is known as " Third Industrial Revolution"(Ward, 2019). Different social media enterprise like Twitter, Facebook, Instragram etc. provide common people platforms to express their opinions about all most all contemporary topics besides sharing personal updates. Twitter is a leading player in this category. It can reflect people's sentiments, problems and views on C.AA./N.R.C. A survey on twitter post on this topic between 28.12.2019-5.1.2020 had collected 18 thousand tweets State wise. Out of 18 thousand tweets, analysis show 7 thousand neutral, 3thousand 2 hundred negative and 2 thousand positive. Keralite people's opinions were mainly negative as Islam is I of major religion of this State. U.P. and Haryana's public opinions were positive. Tweets from Delhi and surrounding regions were very negative and critical due to mass-agitations in Saheen Bag, Jamia-Milia-Islamia etc.(Srivastava \& Eachempati, 2021).

After passing C.A.A. 2019, violent agitations broke out in Assam which killed 7 people and destroyed public properties. The main cause of this agitation were mainly 2 .A] Assam Accord in 1985 fixed ultimate settlement time limit of migrants as 24,3.1971 But C.A.A. 2019 extend the limit up to 31.12.2014.

B] Final N.R.C. draft in 2019 had categorized around 19 lakh people as "Illegal Migrants". However there was strong conception among Assamese people that at least 5 million illegal migrants had settled/occupied in different Assamese Districts. This idea was fueled by statement of People's representatives in both Central and State Legislative bodies' during past decades. Between 19912011 Muslim population in Assam increased by $5.79 \%$ while Hindu population decreased by $5.66 \%$. It hugely changed demography of Assam. Though first Indian Prime Minister J. Nehru. Promised to protect Assam's tribal land culture through "Panchashil Tribal Principles" 
in the Constituent Assembly(K, 2019). There is fear among ethnic-Assamese people that they will be declared minorities in their forefather's land. Besides common people, B.J.P. Finance Minister of Assam Dr. H.B. Sharma, A.P.W. leader A.Sharma, A.A.S.U. leader Dr. S.Bhattacharya, President of Assam Gana Parishad expressed their disappointment about no of excluded people, and decided to appeal again to Indian Supreme Court for re-verification and correction of N.R.C(Gopal, 2021).

\section{CONCLUSION}

In this article, I have tried to analyses changing pattern of citizenship concept in India on the background of N.R.C and C.A.A. It is true that any sovereign Nation-State can not bear economic burdens of illegal migrant's for unlimited time period. And it is duty of every State to protect cultural identities of each residing communities. At the same time it is also fact in a 3rd world country like India, majority of people struggle to earn day to living money. It is almost impossible for them to acquire proper academic and economic efficiency to include their name in updated N.R.C. It is my humble opinion that verifying administration should be considerate about these backdrops. Not but the least, people and opposing political parties should be careful while opposing this necessary process. If any person from any religious-ethnic-economic background can provide valid Aadhar Card issued before 2014 to these verifications, helshe will be exempted from bearing burden of acquiring huge quantities of other documents. News media operating on online/ offline platform should participate in decreasing false gossips and public panic about N.R.C. and C.A.A.

\section{REFERENCES}

[1] A distraught tribal: The genesis of Assam ethnic violence. (2012, January 17). The Economic Times. https://economictimes.indiatimes.com/news/politics-andnation/a-distraught-tribal-the-genesis-of-assam-ethnicviolence/articleshow/15458830.cms

[2] Ahmed, S., \& Khan, S. A. (2019). Future of Citizenship Laws in India With Special. 6(4), 268-277.

[3] Anand, R., \& Dubey, A. (2018). National Register of Citizen of India ( Nrc ). The Law Brigade (Publishing) Group, 4(5), 280-289.

[4] Citizenship | definition, history, \& facts | britannica. (2022). In Encyclopedia Britanika. https://www.britannica.com/topic/citizenship

[5] citizenship / Etymology, origin and meaning of citizenship by etymonline. (2022). In Etymology Dictionary. https://www.etymonline.com/word/citizenship

[6] Contractor, Q. (2021). Feminizing Citizenship: Why Muslim
Women Protest against the CAA. PS - Political Science and Politics, 54(4), 639-640. https://doi.org/10.1017/S104909652100069X

[7] Definition of illegal alien/immigrant. (2022). In MerriamWebster. https://www.merriamwebster.com/dictionary/illegal+alien\%2Fimmigrant

[8] Gopal, M. N. (2021). Citizenship debate over NRC and CAA: Assam and the politics of history. SAGE Publications India Pvt Ltd.

[9] Haynes, D. E., \& Roy, T. (1999). Conceiving mobility: Weavers' migrations in pre-colonial and colonial India. Indian Economic and Social History Review, 36(1), 35-67. https://doi.org/10.1177/001946469903600102

[10] History of citizenship. (2021). In Wikipedia. https://en.wikipedia.org/w/index.php?title=History_of_citize nship\&oldid $=1063021519$

[11] India is home to 224 million child brides, and counting, but that number can be reduced by one-third, suggests a study. (2021, February 1). Gaonconnection | Your Connection with Rural India. https://en.gaonconnection.com/india-childmarriage-covid19-pandemic-rural-girls-education-schoolhealth/

[12] Jayal, N. G. (2013). Citizenship and its discontents: an Indian history. Harvard University Press.

[13] K, P. (2019). Jawaharlal nehru's tribal panchsheel. In Praveenkumar's Blog. https://praveenkalikeri.wordpress.com/2019/10/11/tribalpanchsheel/

[14] Mamata Banerjee on CAA, NRC: I am your 'pehredar', will not let anyone snatch your rights. (2020, January). The Indian Express. https://indianexpress.com/article/india/mamata-banerjee-oncaa-nrc-they-will-have-to-do-it-over-my-dead-body6204474/

[15] Mander, H. (2018). Report on NHRC Mission to Assam's Detention Centres from 22 to 24 January, 2018. January.

[16] Mukherjee.Trisha. (2022, February 2). Racism and alienation: north-east indians fleeing insurgency find no solace in delhi. Https://Www.Outlookindia.Com/. https://www.outlookindia.com/website/story/india-news-theplight-of-northeasterners/407107

[17] Nirvaan.S.A. \&Goel. N. (2020). ANALYSIS OF NEXUS AMOGNST CAA, NRC \& NPR. GIBS Law Journal, 2(1), $1-7$.

[18] Poverty in india. (2022). In Wikipedia. https://en.wikipedia.org/w/index.php?title=Poverty_in_India \&oldid=1064757121

[19] Sen.A.P. (1957). Gitigunja- (3rd ed.). sadharan brahmo samaj. archive.org/details/in.ernet.dli.2015.303748

[20] Separatist movements of India. (2021). In Wikipedia. https://en.wikipedia.org/w/index.php?title=Separatist_move ments_of_India\&oldid=1062592272

[21] Srivastava, P. R., \& Eachempati, P. (2021). Gauging Opinions About the Citizenship Amendment Act and NRC. Journal of Global Information Management, 29(5), 176193. https://doi.org/10.4018/jgim.20210901.oa10

[22] Sufian, A. (2020). Geopolitics of the NRC-CAA in Assam: Impact on Bangladesh-India Relations. Asian Ethnicity, 
OO(00),

1-31.

https://doi.org/10.1080/14631369.2020.1820854

[23] Tiwari, A. D., \& Singh, P. (2021). Experiencing the violence of law: Contextualising the NRC process in Assam. Jindal Global Law Review, 12(1), 29-54. https://doi.org/10.1007/s41020-021-00148-3

[24] Varghese, G. C., Naveet, A., \& Kishore, M. (n.d.). Love thy Neighbour.

[25] Ward, K. (2019). Timeline of revolutions | mds events newsroom. In MDS Events. https://manufacturingdata.io/newsroom/timeline-ofrevolutions/ 